\title{
POLICY IMPLEMENTATION IN ACHIEVING BASIC COMPLETE IMMUNIZATION AND UNIVERSAL CHILD IMMUNIZATION INDICATORS IN KAPUAS DISTRICT IN 2018
}

\author{
*Lia Rosi Vela, **Amal Chalik Sjaaf
}

\begin{abstract}
* Health Policy and Administration, Faculty of Public Health, Universitas Indonesia, Kampus Depok, Jawa Barat, 16425 , Indonesia

** Health Policy and Administration, Faculty of Public Health, Universitas Indonesia, Kampus Depok, Jawa Barat, 16425, Indonesia
\end{abstract}

Email : liarosivela@ymail.com

\begin{abstract}
Completing the basic immunization and implementing Universal Child Immunization (UCI) are the objectives for the Immunization Program according to the Ministry of Health of Republic Indonesia Strategic Planning. In 2017 , Kapuas district achieved $66,6 \%$ of the Completed Basic Immunization target and 32,2\% of the Universal Child Immunization (UCI) target. There is still a 26,4\% gap and a 62,8\% gap, respectively, from the $95 \%$ target of Strategic Plan Ministry of Health 2015-2019. This study aims to discuss the performance of policy implementation of Completed Basic Immunization (CBI) and Universal Child Immunization (UCI) in 2018 at Kapuas Regency, using qualitative research with case study design at 6 Puskesmas in Kapuas Regency. The total informants in this research are 34 informants. The study showed that the performance of policy implementation regarding indicator achievement of CBI and UCI of Kapuas Regency in 2018 have not been optimal. So, policy improvement is needed to increase CBI and UCI achievement of Kapuas Regency next year.
\end{abstract}

Keywords: Immunization, Complete Basic Immunization, Universal Child Immunization (UCI), performance of policy implementation

\begin{abstract}
Abstrak. Indikator yang diukur untuk menilai kinerja pelaksanaan imunisasi di Indonesia berdasarkan Renstra Kemenkes RI adalah pencapaian imunisasi dasar lengkap (IDL) sedangkan indikator programnya adalah pencapaian universal child immunization (UCI). Pencapaian indikator IDL Kabupaten Kapuas pada tahun 2017 sebesar 66,6\% di mana selisih ada selisih 26,4\% dari target Renstra Kemenkes RI 2015-2019 sebesar 95\%. Pencapaian indikator UCI desa/kelurahan Kabupaten Kapuas Tahun 2017 sebesar 32,2\% dan ada selisih 62,8\% dari target UCI berdasarkan RPJMN sebesar 95\%. Tesis ini bertujuan untuk membahas kinerja implementasi kebijakan terkait pencapaian indikator imunisasi dasar lengkap (IDL) dan Universal Child Immunization (UCI) tahun 2018 di Kabupaten Kapuas. Penelitian ini adalah penelitian kualitatif dengan desain rapid assessment procedure (RAP) yang dilaksanakan di 6 puskesmas yang berada di kabupaten Kapuas. Jumlah informan dalam penelitian ini ada 34 informan. Pengumpulan data primer dilakukan dengan wawancara mendalam dan observasi melalui telaah dokumen dan kemudian dilakukan analisis data kualitatif. Hasil dari penelitian menunjukkan bahwa kinerja implementasi kebijakan terkait pencapaian indikator imunisasi dasar lengkap (IDL) dan Universal Child Immunization (UCI) di 6 puskesmas yang ada di kabupaten Kapuas tahun 2018 kurang optimal sehingga diperlukan upaya perbaikan untuk meningkatkan pencapaian IDL dan UCI di tahun berikutnya.
\end{abstract}

Kata kunci: Imunisasi, imunisasi dasar lengkap (IDL), Universal Child Immunization (UCI), kinerja implementasi kebijakan

\section{INTRODUCTION}

Immunization is an endeavor to actively raise or enhance one's immunity against a particular disease. Therefore, if someone is exposed to a particular disease, he/she would not likely get ill or only experience mild illness. Immunization is also one of the health interventions that is proven to be the most cost-effective because it can prevent and reduce the incidence of morbidity, disability, and death due to immunizationpreventable diseases (PD3I) which caused 2 to 3 million deaths annually (1). Republic of Indonesia constitution number 36 of 2009 (2) also regulates the health of 
infants and children in article 130 (3).

The immunization program for infants is designed to make every child get a complete basic immunization. A basic immunization program for children is considered to be successful if it is measured through complete basic immunization indicators (IDL) (1). IDL indicators, based on the Strategic Plan from Presidential Decree Ministry of Health number 52 of 2015, have reached 93\% (4). Universal Child Immunization (UCI) in the village/small regional area is defined as a condition where $80 \%$ of babies (0-11 months) in the village / small regional area have received complete basic immunization (1). Based on the Strategic Plan, the UCI indicator must reach $95 \%$ to be considered as successful.

Central Kalimantan had reached $80.32 \%$ of 2016 IDL indicators with still a $12.68 \%$ difference from the target based on Strategic Plan 2015-2019, which was 93\%. While UCI indicator in 2016 had been reached for only $65.5 \%$ with a $29.41 \%$ difference gap from the target, which was $95 \%$. The achievement of IDL indicators in Kapuas district in 2017 was $66.6 \%$, which has the $26.4 \%$ gap from the $95 \%$ Strategic Plan target for 2015 2019 .

The highest UCI achievement (100\%) in Kapuas Regency in 2017 is in the villages in Strait and Melati Puskesmas Jurisdiction. Moderate UCI achievements $(50 \%)$ are in the villages in the Barimba and Tamban Baru areas while the lowest UCI achievements $(0 \%)$ were in Palingkau and Palangkau villages which meant that no village in those areas achieved completion of basic immunization that is $80 \%$.

\section{METHODS}

The study was conducted in January-February 2019. Data collection is done through in-depth interviews and observations through document review. The number of informants in the study was 34 informants who came from the Regional Government, Health Office, Pharmacy Warehouse, Puskesmas located in the Strait, Melati, Tamban Baru, Barimba, Palingkau and Palisaran, and representatives of parents in the area of Kapuas Regency.

The process of data analysis begins by compiling transcripts of voice records from 34 informants, then coding the data by identifying words or paragraphs that can be used. After that, we simplify them into matrices, identify the variables and relationships between variables so that conclusions can be drawn and compared with other theories and research results.

\section{RESULTS AND DISSCUSION}

\section{Policy Implementation}

Based on document review, there is an increase in the IDL achievement $(90,46 \%)$ and Universal Child Immunization (UCI) $(88,46 \%)$ indicator in 2018 compared to 2017 achievement. Those are the result of the policies implementation on complete basic immunization (IDL) and Universal Child Immunization (UCI) indicators in Kapuas Regency in 2018. The implementations are efforts to increase the capacity of immunization executor through on-job training (OJT) activities at least twice a year. This is in line with research that states that health workers must be trained in reporting basic immunization coverage (IDL) data (5).

According to the document review, Kapuas District Health Office has done monitoring and evaluation in order to evaluate immunization activities at the Puskesmas once a year. Confirmed by the interviews, monitoring and evaluation activities by the Kapuas Health Office in each Puskesmas were properly conducted once a year, while monitoring and evaluation through the PWS (Local Area Supervisors) at the Puskesmas had not run optimally due to Puskesmas internal problems. This result influences the indicator achievement of IDL and UCI in Kapuas Regency in 2018; thus, it has not been able to reach the Strategic Plan target. One study stated that the low UCI achievement in the Kalingkrukut Surabaya Health Center was caused by weakness in (supervision, control, and assessment) where PWS (Local Area Monitoring) had not been fulfilled and did not do the analysis (6). Given the importance of internal monitoring and evaluation at the Puskesmas in immunization activities to improve the achievement of IDL and UCI indicators in Kapuas District in 2018, there is a need to increase the role of PWS (Local Area Monitor) in Puskesmas in immunization activities.

The document review result also stated that routine cross-sectoral approaches were carried out by the Puskesmas three times a year. Confirmed by the interviews, cross-sectoral approaches had been made out through mini-workshop activities and cross-sectoral meetings, but these efforts were still not optimal because Government policies related to immunization were still considered as the responsibility of the Health Administration Office and the Puskesmas itself. This cross-sectoral approach is the basis for understanding network relations (which are horizontal) between work units in the implementation organizational structure (7). Because of the importance of the cross-sectoral approach, this study suggests the Regional Government establish the Immunization Concern Community Forum, which consists of cross-sectoral parties, PKK mothers, community leaders, religious leaders, and 
related parties to improve the achievement of IDL and UCI indicators in Kapuas District.

Dissemination of policies across sectors and communities has been done in two ways, both directly and indirectly. The socialization was intended to increase public awareness and cross-sector cooperation (7).

Based on the document review, the Puskesmas submits immunization activity reports to the Health Administration Office every month, where the report submission limit is at the beginning of each month. There is only one out of six Puskesmas the submitted the report on time. In-depth interviews confirm Puskesmas' lack of discipline to submit periodic reports on immunization activities because there were no selected staff members in the technical record and reporting of immunizations. This information is in line with research that says that doing Fully Immunized Children (FIC) in health services is not easy due to various factors (5). Thus the writers suggest the Kapuas District Health Administration Office and Puskesmas select and train technical staff who are specifically responsible for recording and reporting immunization activities.

Another suggestion is to the Ministry of Health to make an online-based immunization activities record platform that can facilitate recording and reporting activities on immunization activities.

\section{Policy Standards and Objectives}

According to the document review, the standards and policy objectives used were based on Health Minister Regulation number 12 of 2017 about the implementation of immunizations and their derivatives. The standard was in the form of technical guidelines for immunization for Puskesmas. In 2018, the achievement of IDL indicators in Kapuas district was $90.46 \%$, but there was still a $3 \%$ difference from the Strategic Plan target (93\%) as in Minister of Health Decree number 52 of 2015. The UCI village /district indicator was $88,46 \%$ with a difference of $6.54 \%$ from the UCI target set in the Strategic Plan, which is $95 \%$. The causes of IDL and UCI indicators had not reached the targets are due to the unsynchronized data with Pusdatin data (Central Bureau of Statistics), the lack of discipline on reporting or documentation of data, the high mobility of the community, the lack of public awareness of the importance of immunization and people's concern regarding the content of the vaccine.

In determining basic measurement and objectives, statements from decision-makers can be used for regulations and program guidelines that state criteria for policy performance evaluation (8). Many factors have essential contributions in immunization activities such as geographical, social, economic, and political conditions (7). The writers then suggest The Ministry of Health review the achievement targets of IDL and UCI for all regions in Indonesia. This suggestion was made due to all factors that affect the success and failure of achieving national targets for IDL and UCI indicators. The Regional Government and technical Regional Organization (OPD) should analyze the causes of achievement of the IDL and UCI indicators that did not reach the national target and ultimately put the result to the Kapuas District Medium-Term Development Plan (RPJMD).

\section{Inter-Organization
Implementing Activities}

Communication

and

\section{Clarity}

Communication between organizations and implementing activities in immunization is quite clear. Communication is done through the Whatsapp (WA) group can be direct. There are technical instructions and Standard Operating Procedures (SOP) related to the implementation of immunization, which has been socialized to the Puskesmas. Policy standards and objectives can be implemented if explained clearly enough so that executors can know what is expected from these standards and objectives (7).

\section{Consistency}

The Department of Health provides information regarding immunization based on the Minister of Health Regulation number 12 of 2017. This same information has been spread to the Puskesmas. With consistent and clear order information, the implementation of policies can take place effectively (8).

\section{Inter-Organizational Relations}

The relationship between the Puskesmas, the Health Administration Office, and Pharmacy Warehouse is quite good even though the internal supervision of IDL and UCI indicators through the Local Area Monitor (PWS) at the Puskesmas level is still not optimal in each of its working areas. The inter-organizational relationship is interactions between various organizations involved in the implementation process to achieve the objectives (7). Thus, the writers suggest the Health Administration Office optimize the performance of the Puskesmas internal supervisors through Local Area Monitoring (PWS) to monitor the implementation of immunization activities in the Puskesmas itself to discuss the achievement of IDL and UCI in their working area. Community Care Forum needs to be made for Immunization Forum involving cross-sectoral, PKK mothers, community leaders, religious leaders, and related parties in improving the achievement of IDL and UCI indicators in Kapuas District. 


\section{Resource}

\section{Human Resources (HR) and Implementing Disposition}

According to the results of the document review and the results of in-depth interviews, the number of human resources in Kapuas District had been fulfilled, especially for nurses and midwives, while the number of general practitioners still needed to be improved. The quality of human resources in Kapuas Regency still needs to be improved regularly, specifically on knowledge and skills. Commitment and competence are two essential requirements that must be possessed by personnel who are mandated to achieve policy objectives in implementation (7). So that the Central Government through the Ministry of Health should give authority to the regions in terms of acceptance and placement of general practitioners in the area, while we suggest the Kapuas District Health Office form discussion groups for immunization executors at Puskesmas to share knowledge, discuss and analyze together the causes of IDL and UCI indicators in their respective working areas.

The attitude of the implementers towards the immunization program is supportive, even though it is a policy given from the Central Government, but as one of the assessment points in Puskesmas accreditation, the implementers are required to do immunization services. The Health Administration Office and Puskesmas need to increase commitment by implementing compliance with SOPs. It is necessary to monitor and evaluate routine immunization through the Local Area Monitor (PWS) at the Puskesmas.

The implementor comprehension on immunization is still not optimal, so it needs to be improved through On Job Training (OJT) activities held at the Puskesmas at least twice a year, and in these activities, the material is delivered to refresh knowledge and the Health Office as the resource person. The implementor comprehension about general goals or policy standards and objectives is an essential thing in supporting the success of policy implementation (8).

\section{Budget}

Based on data from LKIP (9), the budget allocated for immunization activities is Rp. 160,768,000. The realization of the BOK funds in 2017 is $\mathrm{Rp}$. $11,030,701.902$ while the amount of immunization is unknown (data from the Yankes section). In 2018, the Realization of BOK funds for immunization services in 26 Puskesmas in Kapuas Regency was Rp. $1,882,009,885$. From this data, the budget for immunization is not optimal and needs to be improved to support the implementation of immunization in the Kapuas Regency(8).

\section{Incentive}

From the results of document review and in-depth interviews, there were no incentives or rewards for implementers involved in immunization service activities, even though sources state that funds or incentives can encourage and facilitate effective implementation (8). So it is necessary to have incentives or rewards in the form of bonuses for executors who have implemented immunization services correctly based on the evaluation of the implementer's performance related to the achievement of IDL and UCI indicators by the Puskesmas leaders.

\section{Facilities and infrastructure}

The quantity of supporting infrastructure for immunization in the Puskesmas is sufficient, but the quality is still not optimal. The problem in remote areas are frequent power outages, resulting in vaccine refrigerators can be easily damaged, and lack of commitment from the executors to maintain and care for the vaccine refrigerator. According to Van Horn Van Meter (10), policy implementers must be supported by supporting facilities, like facilities and infrastructure so that the implementation of the policy can be successful. So the Central Government, through the Ministry of Health, needs to use a vaccine refrigerator with a solar cell or solar power for regions with limited electricity, and the implementor comprehension needs to be improved through regular On Job Training (OJT) activities and discussion groups to share knowledge about immunization.

\section{Characteristics of the Implementing Agency}

\section{Mechanism of Standard Operational Procedures (SOP)}

Based on the results of document review and confirmation through in-depth interviews, information was received that the Puskesmas already had technical guidelines for immunization implementation distributed by the Health Office and most Puskesmas already had immunization SOPs based on Minister of Health Regulation number 12 of 2017 concerning immunization implementation. The compliance or commitment from the executors in implementing immunization services according to the SOP is still not optimal, because the executors' mindset returns to old habits. SOPs are used by implementers to utilize the available time and to standardize the actions of highranking officials in a complex organization and broad scope and can generate great flexibility and similarity in implementing regulations (8).

In terms of increasing the executors' commitment and adherence to SOPs, it needs monitoring and evaluation from the Local Area Monitor (PWS) or Pukesmas 
internal supervisors on the implementation of immunization at the Puskesmas itself.

\section{Fragmentation}

There is no fragmentation because implementation responsibilities are not only included in the field of Prevention and Disease Control (P2P) and the surveillance and immunization section in the Health Office, but also coordinates with the Public Health and Health Services department. Fragmentation results in the occurrence of narrow views in most bureaucratic institutions which consequently can hinder the successful implementation

\section{Social, Economic and Political Environment}

\section{Social environment}

In the social environment knows, some people reject policies regarding immunization. The cause of society rejecting immunization is due to a lack of parental awareness about the importance of immunization, religion problems, and wrong perceptions about immunization. Based on data from the 2017 Kapuas district Susenas (11) it was reported that the education level of the community in the Kapuas district was $40.76 \%$ from elementary schools, $44.2 \%$ from junior high schools, and $3.86 \%$ from senior high schools. This data indicates that the majority of education level in Kapuas district community is still in primary / lower education, specifically elementary and junior high schools.

Health policy is strongly related to the community, as the target population, so social aspects cannot be separated from health policies. Various problems in the health sector cannot always be handled properly due to a lack of social and cultural approaches by health policy. Local wisdom of the local community can be changed with an efficient approach such as that carried out by midwives in remote areas and increasing the role of traditional leaders or community leaders (13). So it can be concluded that it needs efficient approaches from the Kapuas District Health Office through a cross-sectoral community health center, community leaders and religious leaders in providing socialization and education to the public regarding the policy on immunization.

\section{Economic Environment}

Based on data from the Susenaas Kapuas district in 2017 (11) it was reported that the percentage of the working-age population in agriculture was 59\%, 34\% in services and $7 \%$ in industry, while the employment in the Kapuas district which provides the highest wages was financial and insurance amounting to 2.7 million rupiahs and the lowest wage is agriculture amounting to 437 thousand rupiah. This data indicates that the economic status of the Kapuas district community is still low, with the majority working in low-income agriculture. Because the majority of farmers spend their time in the fields, they find it difficult to arrange a time to deliver their children to the nearest health center or health facility.

Based on the classification of revenue (14) states that low-income is $<$ Rp. 1,500,000. The economic environment, including economic resources, economic conditions, and factors of production (capital and other resources) can influence health policy instruments and processes (13). It can be concluded that there is a need to increase approach and socialization efforts from the District Health Administration Office Kapuas along with cross-sectoral and community leaders regarding immunization services for the Kapuas district community.

\section{Political Environment}

The District Head of Kapuas is very supportive with thw immunization program. Thus he issued an instruction letter for all relevant Regional Organizations (OPD) such as the Ministry of Religion, sub-district heads, and village heads, to support the implementation of MR immunization activities in 2018. However, cross-sectoral support has not been optimal because not all stakeholders in the region play an active role in improving the community. According to Purwanto (7), the high political content in the implementation process occurs because implementation involves many stakeholders and interaction from actors, both from government and non-government, which raise the political dynamics that accompany the implementation process.

\section{CONCLUSION}

The results of this study indicate that the aspects that have been running well are the characteristics of the implementing agency and the policy standards and objectives, while the aspects that still need improvement are the performance of policy implementation, communication between organizations and implementor activities, resources (HR, budget, incentives, facilities, and infrastructure), and support from social, economic and political environments. So it can be concluded that the implementation of complete basic immunization indicators (IDL) and Universal Child Immunization (UCI) in Kapuas Regency in 2018 was not optimal; thus improvements were needed to improve the achievement of IDL and UCI in the following year. Suggestions for the Central Government through the Ministry of Health are to review the achievement targets of IDL and UCI 
indicators given the limited capacity of the regions with all influential factors, such as the APBN fund allocation used for regions with broad geographical conditions, far and difficult access, develop Onlinebased immunization data integrated with population data, and utilize a vaccine refrigerator using solar or solar cells for areas with limited electricity resources. The suggestions for the Kapuas District Health Office are:

- Increase the role of PWS in Puskesmas in immunization monitoring and evaluation.

- Expand socialization to the community and across sectors.

- Form discussion groups for immunization implementers at Puskesmas to share knowledge.

- Manage periodic training or training to implementers at Puskesmas.

- Encourage regions to allocate $10 \%$ of regional budget funds for Community Health Efforts (smes), one of which is immunization.

- Provide incentives to immunization implementers with good performance.

- Form the Immunization Community Care Forum.

- Bind local policy regulations in the form of regent regulations and regulations villages to local regulations that can support immunization programs.

- Make IDL certificate as a condition for children to enter playgroups and elementary schools.

Improve the implementation of the policy by doing door-to-door engagement.

\section{REFERENCES}

1. Kemenkes RI. Profil Kesehatan Indonesia tahun 2016. Jakarta; 2017.

2. Republik Indonesia. Undang-Undang nomor 36 tahun 2009 tentang Kesehatan. Jakarta; 2009.

3. Kemenkes RI. Peraturan Menteri Kesehatan nomor 12 tahun 2017 tentang Penyelenggaraan Imunisasi, Jakarta. Jakarta; 2017.

4. Kemenkes RI. Keputusan Menteri Kesehatan nomor 52 tahun 2015. Jakarta; 2015.

5. Tsega A, Daniel F, Steinglass R. Monitoring coverage of fully immunezed children. Elshevier. 2014;

6. Arifiyanti I, Wulandari RD. Jurnal Upaya Peningkatan Cakupan Universal Child Immunization (UCI) Wilayah Kerja Puskesmas
Kalingrungkut Surabaya. FKM UNAIR Surabaya. 2012;

7. Purwanto AE, Sulistyastuti DR. Implementasi Kebijakan Publik (Konsep dan Aplikasinya di Indonesia). Yogyakarta: Penerbit Gava Media; 2002.

8. Winarno B. Kebijakan Publik Teori, Proses, dan Studi Kasus. PT. Buku Seru; 2014.

9. Dinkes Kapuas. Laporan Kinerja Pemerintah (LKIP) Dinas Kesehatan Kapua tahun 2017. Kapuas; 2017.

10. Nugroho R. Public Policy. PT. Gramedia, editor. Jakarta; 2017.

11. Badan Pusat Statistik. Indikator Kesejahteraan Rakyat Kabupaten Kapuas 2017. Kabupaten Kapuas; 2017.

12. Republik Indonesia. Undang-Undang Republik Indonesia No.23 tahun 2003 tentang Sistem Pendidikan Nasional. Jakarta; 2003.

13. Ayuningtias D. Kebijakan Kesehatan Prinsip dan Praktik. Jakarta: PT. RajaGrafindo Persada; 2014.

14. Badan Pusat Statistik. Penggolongan Pendapatan Penduduk. Jakarta; 2008. 